\title{
KNOWLEDGE OF “MAGHRIB” (MAYSIR, GHARAR AND RIBA) FOR THE HALAL TRANSACTION OF THE COMMUNITY
}

\author{
Eko Tama Putra Saratian, Mochamad Soelton, and Mugiono, and Muhtadin \\ Universitas Mercu Buana Jakarta, Indonesia \\ Universitas Brawijaya, Indonesia \\ Universitas Prof. Dr. Moestopo (Beragama), Indonesia. \\ tamasaratian@gmail.com
}

\begin{abstract}
This is a community service related to the development of economic community through socialization on muamalah principle and the prohibition of maghrib (maysir, gharar and riba) in the daily transaction. Nowadays, some people in Indonesia have begun to care about the dangers of riba and its impact on the economy. Muslims have believed that riba is haram. Some of them certainly can define as well as interpret the term of riba, but not for maysir and gharar. According to the perspective, Islam always encourages the practice of good muamalah principle and forbids maghrib. Ironically, there are still many ordinary people do not understand the general rules of maghrib. In returning the daily transaction to avoid maghrib, it is necessary to learn deeply about this subject. For this reason, there is a need for socialization to the wider community to increase good understanding of the maghrib and get literacy about sharia transaction well and certainly can be implemented in the daily transaction of community in Indonesia.
\end{abstract}

Keywords: Gharar, Maysir, Muamalah, Riba, Sustainable Finance

\section{INTRODUCTION}

Nowadays, some people in Indonesia have begun to care about the dangers of riba and its impact on the economy. Muslims have believed that riba is haram. Some of them certainly can define as well as interpret the term of riba, but not for maysir and gharar. The failure of the current social economic is caused by the prohibited transaction like maghrib (maysir, gharar and riba). According to the perspective, Islam always encourages the practice of good muamalah principle and forbids maghrib. Ironically, there are still many ordinary people do not understand the general rules of maghrib.

Basically, people without knowledge are sentient and ignorant creatures as the word of Allah Subhanahu Wa Ta'ala "Verily, we have revealed the message to the heavens, the earth and the mountains, then all are reluctant to assume that mandate and they are worried that they will betray it, and be endured. that mandate by humans. Indeed, man is very wrong and very ignorant "(Al-Qur'an, Al-Ahzab, 33: 72). Humans have turbulent passions, always feel lacking and never feel satisfied, according to their character and characteristics. Thus, halal transactions are no longer the main goal because they are often associated with minimal profits, a long and difficult process to obtain. This is also in line with the words of the Prophet Shallallahu 'Alaihi Wasallam, from Abu Hurairah Radhiyallahu 'Anhu, that he Shallallahu 'Alaihi Wasallam said "there will come a time to mankind, they will no longer care about how to obtain wealth, whether through lawful means. or in an unlawful way" (HR. Bukhari).

Rasulullah Shallallahu 'Alaihi Wasallam has also conveyed threats to those who eat illicit wealth. He Shallallahu "Alaihi Wasallam said, "actually will not enter the paradise of meat that grows from illicit wealth. Hell is more appropriate for him" (HR Ahmad and Ad-Darimi). Sustenance must come from a halal source and the purpose of use must also be channeled to those who do not violate the Shari'a, as the words of the Prophet Shallallahu "Alaihi Wasallam "will not shift the footprints of a servant on the Day of Resurrection, until he is asked about four cases, (ie): about: his age for what he spent, about his body for what he used, about his wealth where he got it and where he put it, and about his knowledge, what he had practiced" (HR. At-Tirmidzi and AdDarimi). Likewise from Jabir's friend Radhiyallahu 'Anhu, that the Prophet Shallallahu 'Alaihi Wasallam said: "Do not assume that your fortune is slow down. Truly, no one leaves this world, but after his income is complete. Look for fortune in a good way (by) taking the halal and leaving the haram matters" (HR Al-Hakim and AlBaihaqi).

The urgency of understanding muamalah fiqh is also mentioned in the Qur'an. "They said," Hai Sy'aib, did your prayers tell us to leave what is worshiped by our fathers or forbid us to do what we want about our property. Behold, you are a man of great wisdom and understanding" (Al-Qur'an, Hud 11: 87). Besides that from the friend of Umar ibn Khattab Radhiyallahu 'Anhu, he said "it is not allowed to trade in this market unless people understand (fiqh muamalah), if he does not understand muamalah fiqh, he will eat riba, like or dislike". 
Then atsar from Ali bin Abi Talib's Radhiyallahu 'Anhu, he said "who does business without knowing muamalah fiqh, then he will definitely fall into riba, then more and more and will continue to fall deeper into the practice of riba" (Tarmizi, 2018).

According to Rahmawati (2010), muamalah problems in general are ta'aqqulî (ma'qûlah alma'nâ) because they are problems that continue to develop in accordance with the development of the human mindset in regulating his life. However, there are some basic things in it that must be regulated by the Shari'a to be a sign that must be obeyed by humans (ta'abbudî), so that the life of muamalah man is maintained and organized. The principle of jurisprudence says that the law of origin stipulating conditions in muamalah is lawful and permissible unless there is an argument (which prohibits it). The family is the smallest organization but has a great impact for all its members, one of which is in the formation of a conscious and wise character in transaction and financial management. With this phenomenon, it is felt necessary to disseminate to the public about the dangers of maghrib and its impact on the economy.

\section{LITERATURE REVIEW}

\section{Maysir}

Literally, maysir in Arabic is getting things very easily without hard work or profit without working. Another term used in the Koran is the word 'azlam' which means the practice of gambling. According to Taufik and Masjono (2014), in gambling we depend on profit only on luck alone, even some of the people involved commit fraud, we get what we should not get, or eliminate an opportunity. Game of chance that we depend on the outcome and one party must bear the burden of the other party as a result of the game of chance is called maisir (Hosen, 2009).

Allah Subhanahu Wa Ta'ala shows the prohibition of maysir in the Al-Qur'an as follows:

"O you who believe, verily (drink) khamar, maisir, (sacrifice for) idols, draw lots of fortune with arrows, are abominable acts including devils. So stay away from these actions so that you get good luck. Surely the devil intends to cause hostility and hatred among you because of (drinking) the khamar and gambling, and prevents you from remembering Allah and praying; then stop you (from doing the work) "(Al-Qur'an, AlMa idah, 5: 90-91).

"They will ask you about liquor and gambling, say: in both of them there is a grave sin and benefits for humans. But the sin is greater than the benefit ... "(Al-Qur'an, Al Baqarah, 2: 219).

The prohibitions of maysir from the Hadiths are as follows:

"Whoever declares to his brother, 'Come, I bet with you.' Then let him give alms" (HR. Bukhari Muslim).

\section{Gharar}

The definition of gharar in language is danger, and taghrir is to bring oneself to something dangerous. Meaning in terms of fiqh gharar has three definitions. First, gharar specifically applies to something whose results are unclear, can or cannot. Second, gharar specifically for commodities with no known specifications. Third, gharar contains two meanings mentioned above. So according to the majority of scholars, gharar is something whose consequences are not clear. In addition, gharar is a transaction in which there is an element of obscurity, speculation, doubt and the like so that from the cause of the existence of these elements results in nonparticipation in the transaction. According to Taufik and Masjono (2014), buying and selling gharar is, all buying and selling that contains obscurity, betting or gambling. In modern transactions, many transaction models are included in the gharar category. (Hosen, 2009).

Allah Subhanahu Wa Ta'ala shows the prohibition of gharar in the Al-Qur'an as follows:

"And let no part of you eat the treasure of some of the others between you and the vanity" (Al-Qur'an, AlBaqarah, 2: 188).

"O you who believe, do not eat your neighbor's property by way of vanity except by the way of trade that applies likewise to you." (Al-Qur'an, An-Nisa, 4: 29).

The prohibitions of gharar in the Hadiths are as follows:

From Abu Hurairah Radhiyallahu 'Anhu, that the has banned the sale of hasah and the sale of gharar (HR. Muslim).

From Ibnu Abbas Radhiyallahu 'Anhu, that the Prophet Shallallahu 'Alaihi Wasallam has banned the sale of gharar (HR. Ibnu Majah).

\section{Riba}

According to Chair (2014), riba is an addition to more than the original capital, riba transactions are usually often found in accounts receivable debt transactions where creditors ask for additional capital from the original to the debtor. Riba is often also translated to mean additional money on capital obtained in a way that is prohibited by Shara ', either with a small additional amount or even with a large additional amount. Riba (interest) has 
become the fad of every conventional financial transaction. This is an idea postulated by the capitalist not minding its implication to the economy in as far as they are accumulating wealth out of it (Mohammad, 2016).

According to Ghofur (2016), the Qur'an itself has explained in detail the stages of the prohibition of riba. The first stage simply describes the negative elements in riba (Al-Qur'an, Ar-Ruum, 30: 39). Then followed by the sign of forbidden riba with the delivery of condemnation of the Jews who practice riba (Al-Qur'an, An-Nisa, 4: 160-161). Next, the Qur'an explicitly forbids riba with the limitation of adh fan mudhā afan (Al-Qur'an, Ali Imron, 3: 130) which is followed by a total prohibition of riba in various forms (Al-Qur'an, Al-Baqarah, 2: 275276).

Allah Subhanahu Wa Ta'ala shows the prohibition of riba in the Al-Qur'an as follows:

"And something riba (additional) that you give so that he adds to human wealth, then riba does not add to the side of God. And, what you give in the form of zakat that you mean to achieve the pleasure of Allah, then (who do so) are the people who multiply (the reward)" (Al-Qur'an, Ar-Ruum, 30: 39).

"So, because of the tyranny of the Jews, we forbid them from eating good food (which was formerly) lawful for them, and because they prevented many (people) from the path of Allah, and caused them to eat riba, when in fact they were forbidden from him, and because they ate people's wealth in a vanity. We have provided for those who disbelieve among them a painful punishment" (Al-Qur'an, An-Nisa, 4: 160161).

"O you who believe, do not eat riba by multiplying and fear you of Allah so that you will have good fortune. Preserve yourself from the fires of hell, provided for those who disbelieve" (Al-Qur'an, Ali Imron, 3: 130).

"People who eat riba cannot stand, but stand like people who are possessed by devils because of (pressure) insanity. That is because they say that buying and selling is the same as riba. Though Allah has justified the sale and purchase and forbid riba. Anyone who gets a warning from his Lord, then he stops, then what he has obtained first belongs to him and his affairs (it's up to) to God. Whoever repeats, they are the inhabitants of hell, they are eternal in it. Allah destroys riba and fertilizes alms. Allah does not like anyone who remains in disbelief and is wrapped in sin" (Al-Qur'an, Al-Baqarah, 2: 275-276).

"O you who believe, fear Allah and leave the rest of riba (that has not been collected) if you are a believer. So, if you don't work (leaving the rest of riba) then know that Allah and His Messenger will fight you. However, if you repent (of riba taking), then for you the subject of your treasure; you are not persecuting nor persecuted" (Al-Qur'an, Al-Baqarah, 2: 278-279).

The prohibitions and threats for usurers in some of the Hadiths are as follows:

From Abdullah bin Hanzhalah, that the Prophet Shallallahu 'Alaihi Wasallam said: "One dirham of riba money consumed by someone in a state of knowing that it is riba money is greater than adultery 36 times" (HR. Ahmad and Ath-Thabrani).

From Ibn Mas'ud, that the Prophet Shallallahu 'Alaihi Wasallam said: "Riba has 73 doors (levels), the lowest (sin) is the same as someone who commits adultery with his mother!" (HR. Al-Hakim and AlBaihaqi).

From Jabir, that the Prophet Shallallahu 'Alaihi Wasallam condemned those who received riba, those who paid it, and those who recorded it, and two of their witnesses, then he said, "They are all the same" (HR. Muslim).

From Aun bin Abi Juhaifa, "My father bought a slave whose job was to burn (to get dirty blood from the body), my father then destroyed the slave's cupping equipment. I asked father why he did it. My father replied, that the Prophet Shallallahu 'Alaihi Wasallam forbade receiving money from the transactions of blood, dogs, and kasab women slaves, he also cursed the work of tattoo makers and who asked for tattooing, receiving and giving riba and he cursed the makers of drawings" (HR. Bukhari).

It was from Abdurrahman bin Abu Bakr that his father said "Rasulullah Shallallahu 'Alaihi Wasallam prohibits the sale of gold and gold and silver with silver unless it is equal in weight, and allows us to sell gold with silver and vice versa as we wish" (HR. Bukhari).

"That he was blessed by two angels and they said, 'Come with us.' Until finally the two angels took him to a river of blood, in the river there was a person who was swimming. Meanwhile on the banks of the river there was one more person. When the person in the middle of the river wants to pull over, the man on the edge of the river throws his mouth with stones, until he returns to his original place (middle of the river of blood). Then the Prophet Shallallahu 'Alaihi Wasallam said:' I asked the two angels about the person who was in the river. 'They answered,' The person you came to, who swam in the river and then his mouth was gagged with stones, he is a usurious eater" (HR. Bukhari). 


\section{IMPLEMENTATION METHOD}

In this Community Service, the methods used are interactive lectures, discussion and question and answer. This lecture was packaged as a socialization activity held on March 14th, 2019 at $09.00-12.00$ at the RPTRA Kampung Baru, Jalan Teratai Kampung Baru RT. 009/010, Kelurahan, Kembangan Utara, Kecamatan Kembangan, Jakarta Barat, DKI Jakarta. This activity was attended by around of 50 students from Al-Washilah 1 Jakarta Vocational School.

The purpose of this activity is to provide socialization and counseling to improve the halal transactions through muamalah principle in North Kembangan, Kembangan, West Jakarta. The objectives of this activity include: (a) increasing public understanding of the principles of muamalah transaction, (b) understanding the prohibitions and negative impacts of maghrib on the economy, (c) providing an introduction to Islamic financial instruments as a solution in managing family finances.

\section{RESULT AND DISCUSSION}

As the forbidden transactions, maghrib are considered by many as a trigger for the crisis. Maghrib is the forbidden transaction in the economic and sources of the problem of all problems. The majority of poverty occurs not because of the unavailability of jobs or low levels of education, far from that this is due to damage to the system resulting from the forbidden transaction. The excessive exploitation of natural resources is also caused by the maghrib system, thus forcing developing countries to pay principal and interest loans with their natural resources. Marghib also causes excessive human exploitation in the end.

So do not be surprised if Allah Subhanahu Wa Ta'ala threatens the perpetrators of maghrib with such a heavy threat and a great sin, as He said:

"O you who believe, fear Allah and leave the rest of riba (that has not been collected) if you are a believer. So, if you don't work (leaving the rest of riba) then know that Allah and His Messenger will fight you. However, if you repent (of riba taking), then for you the subject of your treasure; you do not persecute nor are you persecuted" (Al-Qur'an, Al-Baqarah, 2: 278 - 279).

“...then stay away from unclean idols" (Al-Qur'an, Al-Hajj, 22: 30).

“... and sin leave it” (Al-Qur'an, Al-Mudatsir, 74: 5).

"Indeed, the devil is your enemy, so consider him your enemy, because in fact the devils only invite their class so that they become residents of a fiery hell" (Al-Qur'an, Fathir, 35: 6).

"O son of Adam, do not ever be deceived by Satan as he has brought your two fatherly mothers out of heaven" (Al-Qur'an, Al-A'raf, 7: 27).

"Say: "I take refuge in God (who nourishes and conquers) man. Human king. Human worship. From evil (whispers) devils who are usually hiding, who whisper (evil) into the breasts of humans, from (groups) of genies and humans" (Al-Qur'an, An-Naas, 114: 1-6).

"Verily, my servants have no authority over you, except those who follow you, those who are heretic" (AlQur'an, Al-Hijr, 15: 42).

“...surely I will mislead her descendants, except for a small portion” (Al-Qur'an, Al-Isra, 17: 62).

“...they forget Allah, so Allah forgets them” (Al-Qur'an, At-Taubah, 9: 67).

Furthermore, the Prophet Muhammad Shallallahu 'Alaihi Wasallam conveyed a threat to the perpetrators of maghrib in the following Hadiths:

"Whoever declares to his brother, 'Come, I bet with you.' Then let him give alms" (HR. Bukhari Muslim).

From Abu Hurairah Radhiyallahu 'Anhu, that the has banned the sale of hasah and the sale of gharar. (HR. Muslim)

From Ibnu Abbas Radhiyallahu 'Anhu, that the Prophet Shallallahu 'Alaihi Wasallam has banned the sale of gharar. (HR. Ibnu Majah)

From Abdullah bin Hanzhalah, that the Prophet Shallallahu 'Alaihi Wasallam said: "One dirham of riba money consumed by someone in a state of knowing that it is riba money is greater than adultery 36 times" (HR. Ahmad and Ath-Thabrani).

From Ibn Mas'ud, that the Prophet Shallallahu 'Alaihi Wasallam said: "Riba has 73 doors (levels), the lowest (sin) is the same as someone who commits adultery with his mother!" (HR. Al Hakim and Al Baihaqi).

From Aun bin Abi Juhaifa, "My father bought a slave whose job was to burn (to get dirty blood from the body), my father then destroyed the slave's cupping equipment. I asked father why he did it. My father replied, that the Prophet Shallallahu 'Alaihi Wasallam forbade receiving money from the transactions of blood, dogs, and kasab women slaves, he also cursed the work of tattoo makers and who asked for tattooing, receiving and giving riba and he cursed the makers of drawings" (HR. Bukhari).

"That he was blessed by two angels and they said, 'Come with us.' Until finally the two angels took him to a river of blood, in the river there was a person who was swimming. Meanwhile on the banks of the river there was one more person. When the person in the middle of the river wants to pull over, the man on the 
edge of the river throws his mouth with stones, until he returns to his original place (middle of the river of blood). Then the Prophet Shallallahu 'Alaihi Wasallam said:' I asked the two angels about the person who was in the river. 'They answered,' The person you came to, who swam in the river and then his mouth was gagged with stones, he is a usurious eater" (HR. Bukhari).

\section{CONCLUSION}

From the discussion above, some conclusions can be drawn that based on the verses of the Qur'an, the scholars agree that maghrib is something that is prohibited because it is considered very clear and chronologically the essence of the prohibition can be understood.

Based on the discussion in the previous chapters, it can be concluded that this socialization is expected to increase public knowledge, including: (a) increasing public understanding of the principles of muamalah transaction, (b) understanding the prohibitions and negative impacts of maghrib on the economy, (c) providing an introduction to Islamic financial instruments as a solution in managing family finances.

In addition, Prophet Muhammad Shallallaahu 'Alaihi Wasallam said: "Whoever sees (whatever is) munkar, then change it with his hands; and if he is unable to do so, then with his tongue; and if he is unable to do so, then with his heart; and that is the weakest faith" (HR. Muslim).

\section{REFERENCES}

Al-Qur'an, Al-Karim.

Chair, Wasilul. (2014). Riba dalam Perspektif Islam dan Sejarah. Jurnal Iqtishadia. Vol. 1, No. 1 Edisi 1 98-113.

Ghofur, Abdul. (2016). Konsep Riba dalam Al-Qur'an. Jurnal Economica. Vol. VII, Edisi 1 1-26.

Hadits Bukhari, Muslim, Ahmad, Ad-Darimi, At-Tirmidzi, At-Thabrani, Al-Hakim, Al-Baihaqi.

Hosen, Nadratuzzaman. (2009). Analisis Bentuk Gharar Dalam Transaksi Ekonomi. Jurnal Al-Iqtishad. Vol. 1, No. 1, 53-64.

Muhtadin. (2018). Sosialisasi Yasinan dan Tahlilan dalam Komunikasi Islam, Jurnal Abdi Moestopo, 1(1), 23-29

Mohammad, Ibrahim. (2016). Riba (Usury); a Tool that should be Carved out of Financial Transactions. Turkish Journal of Islamic Economics. Vol. 3, No. 2, 13-24.

Rahmawati, Rahmawati. (2010). Dinamika Akad dalam Transaksi Ekonomi Syariah. Jurnal Al-Iqtishad. Vol. III, No. 1, 19-34.

Soelton, Mochamad and Nugrahati, Tati, (2018). How Complaining Behaviors Effect on Coping Stress and Anxiety?. International Journal of Saudi Journal of Business and Management Studies (SJBMS). Vol. 3, No. 6. 623-628.

Soelton et al, (2019). Gender: Stress Levels on Performance in Modern Industry. International Journal Archives of Business Research (United Kingdom). Vol. 7, No 2, 72-81

Soelton et al, (2018). Toward The Best Strategy In Minimizing The Spread of Drug Users. International Conference on Community Development in Asia. Vol 1. No 1, 171-17

Tarmizi, Erwandi. (2018). Harta Haram Muamalat Kontemporer Cetakan Ke-20. Berkat Mulia Insani.

Taufik, Taufik and Masjono, Ali, (2014). Hubungan Maisir, Gharar Dan Riba dengan Strategi Pembiayaan Berbasis Syariah Di Bank Muamalat Indonesia. Jurnal Politeknik Negeri Jakarta. 351-359. 